\title{
Childbearing and Work-Family Balance among Contemporary Russian Women
}

\author{
ANNA TEMKINA, Ph.D \\ Novartis Chair in Sociology of Public Health and Gender \\ European University at St. Petersburg, Russia
}

\begin{abstract}
There are contrasting views on how gender equality affects fertility in contemporary European societies. This article discusses the Russian situation by asking how tensions in the contemporary gender system relate to reproductive decision-making and identity. How do gendered practices and identities influence women's intentions to have children?

In depth interview data gathered during the last decade is used to analyze how the two main gender contracts of the 'professional women' and the 'working mother' relate to family planning, child birth, pregnancies, and mothering. Results indicate that while Russian women experience increasing pressure of the 'double burden' and few signs of increasing gender equality in domestic life, the stable identity of Russian mothering contributes to the birth of at least one child. Childbearing does not depend directly on gender roles and division of labor in households. The decision to have a child and care for small children continues to be women's responsibility even as fertility patterns have modernized and gender equality in couple relations is slightly increasing. However, the type of gender contract influences the process of negotiation concerning reproductive matters and the timing of childbirth
\end{abstract}

Keywords: Gender equality, fertility, childbearing, mothering, family, work, Russia

\section{Introduction}

Russia and other former socialist countries have low gender equality but high female participation in wage work, and very low contemporary fertility. Russia is especially interesting since it has combined many traditional features of gender and fertility (such as universal and early childbearing) with highly modern traits (such as women's high levels of education and wage work and also large autonomy in reproductive decision-making). This article studies how the gender contracts of the contemporary Russian middle classes relate to women's reproductive decision-making and identity. Fertility behaviour and gender equality may influence each other in significant but also contradictory ways. An attention to gender contracts in families (the roles, practices and identities in domestic sphere) is crucial especially for analyzing reproductive decision-making. 
After a short overview of discussion about relations between fertility and gender I describe how the concept of a "gender contract" can contribute to the interpretation of gendered division of labor and childbearing decisions on the level of everyday life. Then, I provide a short overview patterns in gender equality and childbearing behavior during the last decades in Russia. After the methods section, I discuss the two main contracts of the 'professional women' and the 'working mother' (based on in depth interviews), and how they relate to gender equality, family planning and child birth. I also discuss mothering as the core of female identity in everyday life interpretations of unwanted pregnancy, abortions, and single mothering. ${ }^{1}$

\section{Theory of gender equality and fertility}

Does gender equality have an impact on fertility? And if it does, in what way? The question has no simple answer. While there is a general consensus in demographic literature that "gender equity both within and outside of the family is central factor in understanding low fertility" (Mills et al. 2008, 20), there are different claims as to how exactly childbearing relates to gender ideology and attitudes, the labor market, and the division of household work (see e.g. McDonald 2006).

Scholars agree that the relationship between gender equality and fertility is not straightforward. The second demographic transition to low fertility and very low fertility levels has been connected to a high degree of individualism, increased gender equality in wage work, and changes in gender ideology towards more egalitarian patterns (Henz 2008). Thus the overall growth of gender equality has been associated with a decline in fertility. Women with more modern attitudes also tend to have less children (Westoff and Higgins 2009, 71).

But today, childlessness is relatively low and fertility relatively high in egalitarian Sweden (probably due to family policies, the childcare system, parental leave and parental benefits) (Oláh and Bernhardt 2008; Westoff and Higgins 2009). Italy represents a country with low gender equality, low labor market participation and a total fertility rate around 1.3, while the Netherlands has moderate to high gender equality, high part-time female labor market participation and a TFR around 1.8 (Mills et al. 2008, 1,2, 18-20). Thus gender equality may now be associated with higher levels of fertility. As Livia Oláh and Eva Bernhardt conclude, gender equality "may on the one hand contribute to delayed childbearing, and, on the other, favor 'recuperation' and thus lead to higher completed fertility" (Oláh and Bernhardt 2008, 1136). Women's participation in the market is crucial, as well as the division of labor of household and the possibilities to combine different gender roles (Mills et al. 2008, 3).

1 I thank Anna Rotkirch, Elena Zdravomyslova, Sergey Zakharov and anonymous referees for comments and Maria Roti for language correction. 
The role of men's attitudes and behavior is also unclear. From one side, it is argued that men with egalitarian attitudes desire and also actually have more children than do more traditional men (Puur et al. 2008). However, negative association between men's egalitarian attitudes and fertility is reported by other scholars (Westoff and Higgins 2009). Gender equity may also affect the timing rather than the overall number of children as well as the relative impact of the value of children on childbearing decisions.

As Ursula Henz $(2008,1451)$ has shown regarding fertility and the value of children in East and West Germany, couples "that practiced a patriarchal division of labour had a relatively high first-birth rate whereas less traditional couples' behaviour was more varied depending on their affective value of children".

Charles F. Westoff and Jenny Higgins $(2009,72)$ claim that "some measure of gender egalitarianism in some countries appear to be positively associated with higher fertility, while other measures are negatively associated". The gender system may impact other influences on fertility "rather than create it outright" (Westoff and Higgins 2009, 72). Anneli Miettinen, Anna Rotkirch and Stuart Basten (in press) conclude their research on gender role, attitudes and fertility intentions in Finland that "gender equity and family values influence fertility independently and should not be confused with each other".

Explanations of current low fertility in Ukraine (and Russia as well) include economic inequality, societal-level stress and anomie, changing values and belief system, and gender inequality (Perelli-Harris 2008, 1160), of which we are interested especially in the last one. Because research on the topic has witnessed a lack of consensus on how to measure gender equality (Westoff and Higgins 2009, 71) I use the concept of "gender contract" as an analytical tool to analyze selected cases of fertility decisionmaking, behavior and related issues in Russian middle class families. This concept helps to highlight negotiated gender division of labor in private and public spheres as related to the issues of childbirth decision.

The gender contract is a dominant type of gender relations in a particular society. It denotes the explicit and implicit rules, reciprocal responsibilities and rights that define the relations between women and men, between different generations and between the spheres of production and reproduction (Mills et al. 2008, 2-7; Rantalaiho 1994, 19). Childbearing is obviously a crucial part of the sphere of social reproduction, defined as the "activities and attitudes, behavior and emotions, responsibilities and relationships directly involved in the maintenance of life on a daily basis social reproduction includes how good clothing and shelters are made available for intermediate consumption, the ways in which the care and socialization of children are provided" (Laslett and Brenner 1989, 382-83). "The everyday contract is sustained through routine behaviour, relationships, attitudes and unarticulated knowledge" (Kravchenko 2008, 67). 
Here, I use the concept of gender contracts to analyze it's relation to fertility on different levels of the gender division of labor in Russian middle class, which are characterized by combinations of modern and traditional norms and practices, which could have a contradictory influence on childbirth decision-making:

- The gender division of labor between public and private spheres,

- The gender division in the private sphere (the household organization)

- domestic (caring for people and things)

- intimate (emotional and sexual) relations, with the focus reproduction: family planning, and child birth (Henz 2008, 1458, 1467; McNay 1999, 112; Mederer 1993)

\section{Fertility trends and gender in Russia}

Soviet gender politics imposed a gender contract of 'working mother'. It presupposed women's responsibility for children and household and the possibility of combination of public and private roles under the state support (Kravchenko 2008; Rotkirch and Temkina 1997). Women were mobilized as a reproductive force, supplying the state with citizens, and as workers, the state used women as a labour resource. Demographic and economic problems were tackled using proscriptive and mobilizing measures. The official discourse of the Soviet "superwoman" and her symbolic representations developed. The formula of the double burden of wage and domestic work became part of the stereotype of women officially presented as 'normal' and acceptable. It was also internalized by succeeding generations of Soviet female citizens. A limited liberalization of gender politics in the 1960s did not question women's main responsibility for the domestic sphere (Temkina and Zdravomyslova 2005). And while Soviet women struggled under a double burden, they nevertheless often "chose to have more that one child" (Perelli-Harris 2008, 1166).

The first demographic transition ended in Russia in the 1960s as the total fertility rate dropped below 2 children per woman (Zakharov 2008, 916-19), During the late Soviet period dual employment of spouses, formally equal gender rights and gender inequality in the family influenced fertility. Liberal divorce and abortion legislation and changes in sexual practices made pre- and extramarital sex, out-of-wedlock births and divorces common. At the same time, some traditional patterns were preserved, including a strong link between sexual and matrimonial behavior, little knowledge of and access to modern contraceptives, premarital pregnancies as a stimulus for marriage, formation of the family at a young age, the absence of regulation of the timing of childbirth, and no voluntary childlessness. (Zakharov 2008, 916).

The post-Soviet transformation from 1991 onwards challenged the previous gender system, including public and private roles and the organization of intimate life. The fertility rate declined and the TFR dropped to 1.4 , and even below 1.0 in some areas 
(Zakharov 2008, 922). Fertility patterns also began to change; but marriage and childbirth were still characterized by early timing and universality. Thus nearly all Russian women have been married and have had at least one child The level of childlessness remains low (Rotkirch and Kesseli 2009; Sakevich 2009; Sinyavskaya, Zakharov and Kartseva 2007; Philipov and Jasilioniene 2008). "There is no doubt, - Sergei Zakharov claims - that the fertility of the cohorts born in the 1970s and 1980s will be lower than that of those of the 1960s" (Zakharov 2008, 947)

Russian rates of both marriage and divorce remain very high in a European context. The dominant fertility ideal is two children, while the actual number of children, currently around 1.5, is smaller than during Soviet times. However, some kind of a second demographic transition or quiet revolution occurred in the mid-1990s. The cohort born in the 1970s and more recently marry become parents at more mature ages and delay the first and the second birth. They also prefer to "begin a partnership with cohabitation rather than with legal marriage". (Zakharov 2008, 931-32.)

Family planning has become much more effective. The numbers of abortion per woman have fallen and contraceptive use has improved especially regarding condoms. However, although around one quarter of adult women use no safe contraceptive method although they did not wish to become pregnant. Partly as a consequence of this, the birth of the first child is mostly unplanned while the second child (if there is any) is typically planned. (Perlman and McKee 2009; Rotkirch and Kesseli 2009; Regushevskaya et al. 2009; Sakevich 2009; Zakharov and Sakevich 2008)

In sum, many studies provide some evidence of a convergence in Russian and other European patterns of childbearing, being at the same time challenged by the "deviance" of some trends compared to other Western countries. These include the continued Russian pattern of early timing of marriage and childbirth, the low level of voluntary childlessness and the absence of effective family planning in couples. (Vishnevskii 2006: 139, 141, 175). Modern and traditional features of fertility are intertwined in the patterns of childbearing.

Combination of traditional and modern traits characterizes contemporary ambivalent gender politics and ideology in Russia, Official gender contract was "reformulated" during post-Soviet privatization, economic troubles and disintegration of welfare Contemporary state policy promotes the "dual earner" gender contract. However, it does not improve radically the conditions for work and family reconciliation for women, nor does it promote gender equality in the labor market and within households (Kravchenko 2008; Rotkirch and Temkina1997).

Gender ideology has changed in different directions. On the one hand, motherhood and nurturing remain basic attributes of official discourse. Traditional patterns of motherhood combine with increasing pressure from traditionalist ideology. The Orthodox 
Church demanded reinforcement of spiritual and family values, and a renewed feminine image of maternity and domesticity. Religious authorities claim that these values were destroyed by spiritual decline and other consequences of Soviet gender politics as well as by foreign Western influence advocating free abortion, family planning and sexual education (Snarskaya 2009). Contemporary Russian official ideology stresses that women have a gender-determined civil entitlement: the demographic reproduction of the nation. In the 2000's childrearing and supporting the household are regarded as matters of state interest, assistance and concern (Rivkin-Fish 2006; Temkina and Zdravomyslova, 2005). Policies typically promote maternity (not parenthood) as high value. For instace, all recent suggestions concerning family and child care policy in the mid 2000s are oriented towards assisting working mothers ("maternal capital" and other maternal monetary benefits, for details see Zakharov 2008, 930-31). Thus the balance of work and family is articulated as a problem for women only (Rotkirch, Zdravomyslova, and Temkina 2007).

On the other side, however, there also exist egalitarian trends in society in both the public and private spheres in the 1990s-2000s. The shift in women's gender roles has been towards the role of professionally (or career) oriented, as well as a value shift towards career, material goals, autonomy and self interest, and more egalitarian gender patterns in sexual sphere characterized the new generation (Perelli-Harris 2008, 1064; Rotkirch and Haavio-Mannila 2000; Sinyavskaya et al. 2007; Temkina 2008; Vovk 2006). Research results indicate a general trend toward increasing equality in intimate and sexual life and its liberalization. The value change of the sexual revolution is part of women's emancipation and a weakening of the gender divide (Kon 2002).

Different gender roles became legitimate for women (e.g. ,working mother', ,professional women', ,housewife'). The level of labour participation of women in Russia is high, exclusive motherhood is not typical, and women are still mostly resposible for child care domestic chore (Chernova 2008; Kravchenko 2008; Sinyavskaya et al. 2007). The most common gender contract is that of the ,working mother ${ }^{6}$ - wage working women who have the main responsibility for domestic work (Kravchenko 2008; Temkina and Rotkirch 1997). However, housewife gender contract is acceptable in contermporary Russia and there is a segment of those women who choose traditional family role and withdraw from waged labour (at least temporally) if their husbands are successful breadwinners role. We concentrate here on two other types of gender contract where women intend and have to combine roles of waged labor and childbearing.

Under market conditions, changes in infrastructure, values and ideologies the demands of both professional and maternal roles and identities for working women grew stronger in the case of their combination. Individualistic intentions, career orientations, materialistic and consumer values make wage labor roles more important for women. On the other side, market uncertainty makes wage labor roles compulsory for many women. 
The majority of women face threats that are associated with market uncertainty and could not withdraw from wage labor for a long period under economic pressure and risks for their qualification, career, and safety of working position (Ashwin 2006, 1). According to data of the survey "Parents and children, men and women in Family and Society" (2004), $81 \%$ of women were in wage labor, $18 \%$ not working (Sinyavskaya et al 2007, 435). At the same time the birth of at least one child continues to be a social norm (Sinyavskaya et al. 2007, Vishnevskii 2006). However, conditions for a combination of the roles of worker and care deteriorate. Social stratification and economic competition is harsh and services for families with children have deteriorated. For instance the availability of childcare facilities has declined by four times, and the role of intergenerational help continues to be significant (Sinyavskaya et al. 2007, 427, 449). Nowadays the 'double burden' makes women often choose to have only one child.

Let us now look at the how the gendered organization of everyday life intertwines with reproductive strategies and fertility for different gender contracts among middle class women. We discuss the two most typical gender contracts for younger educated couples: the \professional woman' and the 'working mother'. The 'working mother' is the most widespread, while the gender contract of the professional couple and career orientated women is significant and especially interesting with regards to gender equality.

\section{Data and methods}

My methodological approach is based on the sociology of everyday life and on research which was done by qualitative methods (recorded and transcribed in depth-interviews) during the last years. My aim is not to measure the relationship between gender equality and fertility, but rather to interpret some shifts in terms of gender contracts. I will study childbearing decisions on the level of micro and subjective decisions in everyday life. I use data from the interviews conducted in different research projects in 2004-2009. Young women and men, as well as couple in cohabitation (man and women separately) were interviewed (list of 19 cited informants - 16 women and 3 men, see Appendix) All interview has guide, and being focused on cohabitation, gender roles and caring and/or sexual and reproductive practice, all of them includes questions about childbirth decision-making, family planning, negotiations of partners and participation of men, as well as relation to single mothering, unplanned pregnancy and abortions. I use thematic coding for data analysis.

The interviews were conducted in several large Russian cities: St.Petesrburg, Samara, Kazan' and Arkhangelsk. Respondents represent the urban middle class. Thus rural or ethnic communities are not included, nor the peasant milieus that characterize the less urbanized parts of Russia. Nevertheless, the urban middle class is symbolically important in society. They are often the forerunners of new practices and set standards towards which other social groups orient themselves. It is also important to take into 
account that in the case of the middle class we could expect relative reduction of the influence of impoverishing conditions.

\section{Results and discussion}

This section proceeds to show how the two gender contracts of the 'professional women' and the 'working mother' relate to reproductive decision making. I describe women's orientation toward work-family balance, family planning, gender division of labor in household, partnership behaviour, and mothering. A stable identity of Russian mothers and role conflicts characterize both cases. In the first case, higher gender equality, the career interests of women and negotiation between partners result in family planning and regulation of timing of childbirth. By contrast, in the second case women's career is not so important and the maternity role is taken for granted. Though women's role balance limits the number of children, mothering per se remains unquestioned, Women's responsibility for reproductive decision making and for child care feeds into cultural acceptance of single mothering as well as to the limitation of subsequent births.

\section{The 'professional woman' gender contract}

"One is certain, probably there will be two children, a third is too serious. ... This mostly depends on women".

Let us start with a case of a professional, career oriented woman living in cohabitation. Katiya, 29 years, and Yuri, 32 years, (both interviewed in St. Petersburg, 2009) have lived together for 8 years. Katiya is the director of a large department firm. Yuri is an engineer in high-technology. For three years Katiya worked in Moscow, and by her own words, "it was a high point in her resume", by the words of Yuri, he "encouraged" her to be there. In that moment they lived together apart. Both emphasized the significant step of autonomy which included parallel sexual relations. By Yuri's own words Katiya salary is significantly higher, but they put money in equally in the household, or they paid for themselves. Both partners emphasize the role of negotiation in their relationships. A gender division of labor in the home was not recognized, but a significant part of the housework was carried out by a paid housekeeper. Katiya thinks that Yuri is not interested in the participation to the daily life.

The couple has a strategy of contraceptive use. They did non plan to have a child before, but now they plan to have a child and therefore, intend to register their marriage. The initiative comes from Katiya. On the question of how many children they want to have, Katiya said that an ideal number would be three, "two to replace them and the third for society". Yuri answered that he would like to have three, though "one is certain, probably there will be two, a third is too serious. ... this mostly depends on women". When the child is born, Yuri, like a modern father, intends to take part in the delivery which has traditionally not been the case in Russia (Angelova and Temkina 
2009). Katiya wants Yuri to take an active part in the upbringing of the child; however she believes that she will be more active in this. Yuri thinks that he will participate, but a nanny will be responsible for most of the child care provision. Paradoxically, taken into account Katiay's lifestyle, she describes her ideal life as follows: "It seems to me the ideal is when a man makes a ton of money, I sit at home, I don't do anything, I have a lot of nannies for raising my children, I can engage in some kind of activity from a series of socially-useful things, which does not bring an income, but gives me pleasure. There is, however, a desire for the man also not to so strongly to overexert himself; he should not live to work, working from 9 to 6 , and then return home. That is, he should divide time for me and the kids." Yuri also says that he wants to be active in parenting and to work less, while Katya according to his opinion is a "workaholic".

One child is seen as the most realistic option by both partners, rather than an ideal of having two or three. On the basis of our research on paid domestic labor, we may predict that Katya will return to work soon after the childbirth (eg. 4-6 months) and caring work will be mostly done by a nanny. A second child will be more challenging due to the lack of other main family child carers than Katya (Zdravomyslova 2009).

In cases like Katya's. young professional women are oriented towards family planning. They try to identify the suitable phase of their own and their family cycle for the childbirth, to check their health before becoming pregnant. They do this together with their partner. A similar example comes from the city of Samara. Alena tells (Samara, 2009, 24 years, married, one child), "It was important to have a base in advance, housing, financial base.... My husband began to work earlier during the his studies, and we were self-sufficient ... And then we decided that we could afford a child-after my diploma ... We stopped drinking, smoking, started vitamins and sport etc (laugh). We made a lot of efforts to prepare ourselves" After the decision to have a child Alena stopped to use contraceptives. Alena defines herself and her husband as responsible parents "yes, we are responsible. I am sure people should be responsible". She tells that her husband actively participated in her pregnancy and delivery, "he is a responsible father and husband". After the childbirth she continues writing her thesis. Alena is mostly responsible for childcare and her husband, successful in business, is mostly responsible for breadwinning

The change of gender roles after childbirth from egalitarian to more traditional is expressed by Anton:

"What do you think about the way men's and women's roles in the family should be distributed?

Well, over the period of free relations (unbounded by marriage) I think that everything should be done as we say in a democratic way. It means that if you do not have kids, you don't have any serious responsibilities. When a woman stay at home with 
a baby if will be a different situation, by definition I would to do more. ... And then the man would became the main provider. What can you do-you cannot expect her to do shopping on daily basis. and of course the need will be greater. Probably I will help her (Anton, 30 years).

Similarly to many other societies couples (in West Germany) adapted "a more traditional model of household work when a child was born" , "women, but not man increased their hours of household work when the couple had a child" (Henz 2008, 1459). In this case it is preferable that the father is active in child care, and his is negotiated by the spouses. However, in practice his caring responsibilities remain diffuse, for instance regarding whether he should work more (as a breadwinner) or less (as a carer) when a child will be born and if the woman intends to continue her career at the same time. With the growth of women's individualism and ambitions the gender equality in caring continues to be rather contradictory.

Current trends in the practices of young women like Katya and Alena in relation to gender equality, family planning and child birth include the following:

- women's orientation towards career, work-family balance, and children's number limitation

- family planning beginnings with the first child, an informed choice of contraceptives, decision-making with partner about childbirth, and negotiation about timing of childbirth. Childbearing can be postponed due to challenges of family-work balance.

- relatively egalitarian patterns of role division in the household, or sharing housework. Women do not take all the responsibilities for housework, however men's participation is not totally equal.

- changes in gender roles are expected after the childbirth, and predominantly women's responsibility is expected for child care. Men are intended to participate actively in caring, though their role is negotiated and not clear (help of and paid care may be an alternative)

It could be expected that the first (and second - if any) child is planned, and the childbirth is negotiated and postponed. Even with partner negotiations and signs of gender equality, caring for children remains women's responsibility, and if women intend to combine mothering with career, this is will motivate her to plan and postpone childbirth and to limit the number of children.

\section{The 'working mother' gender contract}

"... maybe two, but one for sure... It depends of different circumstances"

The next case is an example of the working mother gender contract. Dmitry (30 years) and Natasha (27 years) have lived together for three years (2009, St. Petersburg). Both 
work for private corporations. They have a clear division of work and responsibilities. Both also think that the man should earn more than the woman, and that part of domestic work is primarily for women and the other part for men, and their practices coincide with their intentions.

Dmitry tells us about his participation in housework:

"Natasha and my mother have a better idea about the things we need to buy for the house. I go shopping with them and... ask for the food shopping list-this is something women do. So that the food is their responsibility and delivery of food is mine. ..As for cooking - woman do that. I never take part in that, I help with the dishes and with cleaning... Well, I try not to stay away from housework A man must do a work around the house, The work must be divided equally"

Here "equal" participation of both partners is mentioned; however it presupposes rather traditional gender division of labor. In a similar way, the division of labor in her former marriage was described by another professional woman, Kira (34 years), in the following way: "I preferred that my husband not be a part of the kitchen, it was not his business to be there"

Natasha and Dmitry are ready to have a child and to register their marriage. Natasha does not want Dmitry to be present at the birth: "in such it is not a very pleasant thing for him to see such a view of a woman and well, I don't know, probably, it's not the same for men?" It is expected that the main role of child care will be carried out by Natasha. From the husband, during the birth of the child she expects:

Dima, for example, he will arrive from work, he will approach the baby, see, talk, help to buy things, take him for a walk, understandably that maybe he will wash diapers, pampers, and if it will not be very pleasant, well... since he is a man, I will not insist on it.

She expects help from the husband, although the main child care giving remains exclusively in the women's sphere.

Natasha says that she would want to have three children:

"...or maybe two, but one for sure... It depends of different circumstances. Health is important, housing, well-being... Dmitry is ready to work more... but I prefer him to give also attention to family... let's see". Dmitry answers on the same question in the following way: "Two children will be ideal, but a lot of factors influence it, the economic one including and Natasha's health... One child for sure, and one more if possible".

Just as in the previous gender contract, one child is judged as a more realistic option by both partners having the intention to have two or three. The possible perspective for this family is Natasha's return to the paid labor after the birth of the first child. She has no financial possibilities to be a housewife, and caring will be done using 
intergenerational help and state kindergartens. However, if Dmitry will be enougth succesful in his carrier Natasha probably will stay at home (at least temporaly, or working parttime) and probably they also will have a second child.

In this case, we see how both partners work and participate in household labor. However, in contrast to the gender contract of the professional woman, the gender contract of the working mother is more traditional. Gender differences are reported by women and men in expectations and prescriptions for caring and intimate life. Women should take care of the female sphere at home and her partner helps her by doing male tasks. Delivery and caring of infant is understood to be an exclusively female business.

In the above mentioned cases, both partners agreed about these roles. However, the domestic division of work is also a question of negotiations between the adult woman and her mother. It is not expected for men to participate in emotional exchange or intimate negotiations. Contraception is considered to be a women's business due to her own interest in pregnancy prevention and 'due to less control over men's sexual desire'(Nina, 20 years, 2005).

Current trends in the practices of "working mothers" from the educated class of the younger generation in relation to gender equality, family planning and childbirth include

- women's orientation towards wage labor and work-family balance with priority of motherhood (wage work is often necessary for economic reasons). Under economic or other constraints the number of children is limited

- family planning (mostly regarding the second child). The first child is seen as a 'natural' event, and no negotiation is necessary for decision

- clear gender role division in the household. Men participate as 'helper doing traditional men's work at home, while women do women's work

- women's responsibility for child care (with the help of active participation of female relatives). Men's active participation in child care is welcome, but mostly in a traditional way, as a breadwinner or helper.

It could be expected that the first child is a "natural" event (Rotkirch and Kesseli 2010) desired by both partners, while the birth of the second child could be negotiated, planned and postponed under pressure of economic circumstances, women's work demands and main women's caring responsibility even under signs of negotiations and men's help.

Childbearing decisions in both types of contracts conform to results of analysis of decision about second child done by Rotkirch (in press). She argues that the main reasons that educated Russian women hesitate to have a second child relate to economic concerns, health, and personal and social independence. We could specify that the $\backslash$ 
working mother' gender contract features mostly economic reasons as constraints, while the higher paid professional women are more limited by the possibilities of their career and their independence.

Although the gendered division of household work in Russia has generally become more egalitarian, and men take part in household duties women remain mostly responsible for caring and family planning in both types of contracts. Under the pressure of the double burden, high risk of divorce and lack of sufficient state support, women as mothers often prefer to rely mostly on themselves in childbirth decision making and caring.

Some women are ready to make decision about childbirth by themselves. As 27 years old Yulya says: "When I became pregnant (in Living Apart Together-relation) I just told him - I'm pregnant, I will give birth to a baby in any case, If you want we will be in this together... if you don't want ... well... I don 't hold you, I don't ask for money."

Being responsible for childbirth decision making Russian women could theoretically be expected to postpone childbirth, refuse it, or at least carefully plan it until favorable conditions exist. Some women do implement such strategy. But paradoxically, many respondents have the intention to give birth, have a negative attitude to abortions and accept single mothering. Let us finish by looking at these points related to the role of unquestioned mothering in contemporary Russia.

\section{Unquestioned mothering: "I will give birth in any case"}

While some women and men tell about regular use of modern contraception and an orientation towards planned parenthood, other report difficulties with pregnancy prevention, and a negotiated or silent refusal from contraceptive use. Both female and male respondents told us that condoms are uncomfortable for them and contraceptive pills are not safe for their health. Even if they used contraception, it is often neither regular nor reliable, which led to high risk of unplanned pregnancy.

Many young women also said that although they preferred to postpone motherhood, in the case of an unexpected pregnancy, they would give birth to the child. This decision did not depend on their marital or partnership status. Refusal or failure in reproductive planning often "automatically" lead to childbirth, at least in the case of first pregnancy:

If I become pregnant I will give birth in any case. And this does not depend on housing, whether I study or not, whether I work or not, this is not important, I will give birth in any case. (Veronika, 22 years)

Even if I will have no money, no husband... I can not say it definitely of course. But in any case I will not have an abortion until I will have had a first child (Alisa, 22 years)

If there is no medical reason, then there is no sense to do an abortion. And this does not depend on what the partner thinks about it. (Natalyia, 26 years) 
(Abortion) this was a shock for myself for my own values. I pray now. Still there is a frustration. I feel myself as a killer of my child. (Alla, 23 years)

According to such views, the decision about childbirth should not depend on housing conditions, career, and financial situation. It also should not depend on the partner's will:

I'm against abortion... If there is no other choice - she should bring up the child by her own. (Mila, 24 years)

If I become pregnant, I will give birth. This is something divine. (Anna, 28 years)

In our in-depth interviews, abortions were seen as mostly unacceptable in the case of unplanned and unwanted pregnancy, though respondents do not disapprove of women's general the right to abortion, and undesired pregnancies and abortions remain wide-spread. However, many informants say that they do not approve of abortions, even if they themselves had undergone abortions. One of the main reason of disapproval is connected to mothering as abortion evaluated as risky to reproductive health and future pregnancy.

Consequently, our informants generally accepted single mothering. Ideal motherhood occurs together with a partner and under favorable conditions, but single motherhood is better than no motherhood. This is true especially in the case of a conscious choice made by responsible mature women with their own resources. Respondents were more negative towards irresponsible juvenile or a-social mothering:

There are women who have a baby for themselves. I respect them, they bear all responsibility. However I feel pity for the child without normal family. (Vera, 21 years)

If a woman wants to have a baby from a man who does not love her... Then why not give birth? Or she just does not want to live together with him ...I myself will do (this) in such case. (Nona, 22 years)

If she does it for herself - this is good, in order not to be alone in a future, to have support, ..., But if she will refuse the child this is very bad. (Ekaterina, 27 years)

I could l give birth without a partner. My sister did (she is divorced) All help to her. (Nadya, 22 years)

Single mothering is seen as very demanding for the mother who has to be the only breadwinner, but it is not stigmatized.

Maternity is evaluated both in public and everyday discource as a womens destiny and responsibility. Men's help and shared decision-making are judged as important if available, but if they are not, women - including the case of unplanned and unwanted pregnancy - do not want to refuse mothering. They are relying on themselves and on other sources of support. They make the desicions by themselves. However, being a single mother often makes it significantly harder to plan further children. 
Single mothers - whether oriented more towards careers or towards mothering - had to combine wage labor and caring, they took responsibility for both breadwinning and caring (with the help of paid work, intergenerational and state support). A second child in this case is not evaluated as realistic.

\section{Conclusion}

Different factors influence the decline in the numbers of children in Russia. We have here discussed fertility intentions and prospects of Russian middle class. Women are under the increasing pressure of two roles - from one side, the professional role is important for modern identity of the self, which is characterized by individualism and rationality. From the other side, mothering is still absolutely crucial for female identity.

Two gender contracts of contemporary Russian women are in the focus of our attention. Both ,professional women' and ,working mother' face the problem of work-family balance (career demand in the first case and economic needs in the second) and limit the number of children. There is no significant influence of the type of gender relations on the number of children. In the first case less rigid gender division of labor in the private sphere is reported, but childcaring is predominantly women's responsibility. Men's responsibilities are negotiated with the wish to obtain some equal participation. However men do not became equal carers on a regular basis and women should rely mostly upon themselves and paid care. One could expect that the first (and probably second) child is planned, and the childbirth is negotiated and postponed.

The "working mother" contract presupposes more rigid and less negotiated gender roles, more traditional oriented father's participation in caring. Keeping balance for women depends on intergenerational help and state support. In this case the first child is a "natural fact", and birth of the second child (if any) is negotiated and planned, and could be postponed under economic pressure.

Childbirth and caring women tend to have a reduced a number of children (that is, below the desired ideal of a two child family), to keep balance and rely mostly upon themselves. It seems that the decline of state support, family nuclearization with high levels of divorce and lack of male participation in planning and caring for children, combine to make parenting a female project limited to only a few children.

Mothering is mostly unquestionable among Russian women. State familist politics and religious discourse support and feed this view. Family planning practices are often less than ideal, and abortion, although available, is often judged unacceptable, especially regarding the first pregnancy. At the same time, single mothering is articulated as being normal. There are no symptoms in contemporary Russia of any intensive growth of voluntary childlessness or a "childfree sector", as a possible solution of solving 
the work-family balance. Such identity can remain stable even under pressure from professional roles and economic demands, spread of divorces and single mothering and refusing to have a second child.

\section{References}

Angelova, E. and Temkina, A. 2009. Uchastie ottsa v rodah: partnerstvo ili situatsionnyi kontrol'? [Father's participation in the delivery: partnership or situational Ccntrol]. In: Novyi byt v sovremennoi Rossii: gendernye issledovaniya povsednevnosti [New byt in contemporary Russia: gender studies of everyday life], edited by Elena Zdravomyslova, Anna Rotkirch and Anna Temkina, pp. 473-507, St. Petersburg: EUSPb

Ashwin, Sarah (ed.) 2006 Adapting to Russia's new labor market. Gender and employment behaviour. Routledge

Chenova, Zhanna 2008, Semeinay a politika v Evrope I Rossii: gendennyi analis [Family policy in Europe and Russia: gender analysis]. St. Petersburg: Norma

Henz, Ursula. 2008. Gender roles and values of children: childless couples in East and West Germany. Demographic Research [online] 22 August 2008, vol 19, article 39

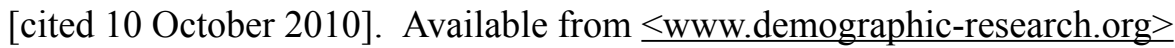

Kon, Igor. 2002. Chelovecheskie sexual'nosti na rubezhe XXI vekov [Human sexualities in the XXI fin de siécle]. In: V poiskakh sexual'nosti [In the search of sexuality], edited by Elena Zdravomyslova and Anna Temkina, pp. 24-47, St. Petersburg: D Bulanin

Kravchenko, Zhanna. 2008. Family (versus) policy. Combining work and care in Russia and Sweeden. Acta Universitatis Stockholmiensis. Stockholm Studies in Sociology. New Series 30.

Barbara, Laslett and Johanna Brenner. 1989. Gender and social reproduction: historical perspectives. Annual Review of Sociology, 15: 381-404

Miettinen, Anneli Anna Rotkirch. and Stuart Basten. 2010. Gender equality and male fertility revisited: the importance of family values. Finnish evidence for a $U$-shaped effect. In press.

McDonald, Peter. 2006, Low fertility and the state: the efficacy of policy. Population and Developmental Review 32(3): 485-510

McKie, Linda, Susan Gregory, and Sophie. Bowlby. 2002. The shadow times: the temporal and spatial frameworks and experiences of caring and working. Sociology 36(4): 897-924.

McNay Lois. 1999. Gender, habitus and the field: Pierre Bourdieu and the limits of reflexivity. Theory, Culture and Society 16(1): 95-117.

Mederer Helen. J. 1993. Division of labor in two-earner homes: task accomplishment versus household management as critical variables in perceptions about family work. Journal of Marriage and the Family 55(1): 133-135.

Mills, Melinda, Letizia Mencarini, Maria LetiziaTanturri, and Katia Begall. 2008 Gender equity and fertility intentions in Italy and the Netherlands. Demographic Research [online] 29 February 2008, vol. 18, article 1 [cited 10 October 2010]. Available from $<$ www.demographic-research.org $>$ 
Olah, Livia and Eva Bernhardt. 2008. Sweden: combining childbearing and gender equality Demographic Research [online] 1 July 2008, vol. 19, article 28 [cited 10 October 2010]. Available from $\leq$ www.demographic-research.org $>$

Perelli-Harris, Brienna. 2008. Ukraine: On the border between old and new in uncertain times/ Demographic Research [online] 01 July 2008 vol. 19, article 29 [cited 10 October 2010]. Available from $\leq$ www.demographic-research.org $>$

Perelman, Francesca and Martin McKee. 2009. Trends in Family Planning in Russia, 1994-2003. Perspectives on Sexual and Reproductive Health 41(1): 40-50.

Philipov, Dimiter and Aiva Jasilioniene 2008. Union formation and fertility in Bulgaria and Russia: a life table description of recent trends. Demographic Research [online] 19 December 2008 vol. 19 article 62 [cited 10 October 2010]. Available from $\leq$ www.demographic-research.org $>$

Puur, Allan, Livia Sz. Oláh, Mariam Irene Tazi-Preve, and Jürgen Dorbritz. 2008. Men's childbearing desires and views of the male role in Europe at the dawn of the 21 st century. Demographic Research [online] 18 November 2008, vol. 19, article 56 [cited 10 October 2010]. Available from $\leq$ www.demographic-research.org $>$

Rantalaiho L. 1994. Sukupuolisopimus ja Suomen malli. In: Naisten hyvinvointivaltion / Ed. by A.Anttonen, L.Henriksson \& R.Natkin. Tampere: Vastapaino. pp.9-30.

Regushevskaya, Elena, Tatiana Dubikaytis, Minna Nikula, Olga Kuznetsova and Elina Hemminki. 2009. Contraceptive use and abortion among women of reproductive sage in St. Petersburg, Russia. Perspectives on Sexual and Reproductive Health 41(1): 51-8.

Rivkin-Fish, Michele. 2006. From "demographical crisis" to "dying nation". The politics of language and reproduction in Russia. In: Gender and national identity in twentieth century Russian culture, edited by Helena Goscilo and Andrea Lanoux, pp. 151-76.

Rotkirch, Anna . 2010 Two children is in the zone of social misery. Childbearing and risk perception among Russian women. In press.

Rotkirch, Anna and Elina Haavio-Mannila. 2000. Gender liberalisation and polarisation: comparing sexuality in St. Petersburg, Finland and Sweden, Idäntutkimus - The Finnish Review of East European Studies, 3-4: 4-25.

Rotkirch, Anna and Katja Kesseli. 2009. Detorozhdenie i ego mesto v zhiznennom tsikle peterburgskih zhenshchin [Childbirth in the life cycle of St. Petersburg women]. In: Novyi byt $v$ sovremennoi Rossii: gendernye issledovaniya povsednevnosti [New Byt in contemporary Russia: Gender studies of everyday life], edited by Elena Zdravomyslova, Anna Rotkirch and Anna Temkina, pp. 426-55. St. Petersburg: EUSPb.

Rotkirch, Anna and Anna Temkina, 1997. Soviet gender contracts and their shifts in comtemporary Russia. Idäntutkimus - The Finnish Review of East European Studies, 4: 6-24.

Rorkirch, Anna, Anna Temkina, and Elena Zdravomyslova 2007. Who helps the degraded housewives? European Journal of Women Studies 14: 349-357

Sakevich, Viktoria. 2009. Problema abortov v sovermennoi Rossiii [The problem of abortions in contemporary Russia]. In: Zdorov'e i doverie: gendernyi podhod k reproduktivnoi meditsine [Health and trust: a gender approach to reproductive medicine], edited by Elena Zdravomyslova and Anna Temkina, pp. 136-52. St. Petersburg: EUSPb 
Sinyavskaya, Oksana, Zakharov Sergei and Marina Kartseva. 2007. Povedenie zhenshchin na rynke rruda I detorozhdenie v sovremennoi Rossii [Women's behaviour in the labor market in contemporary Russia]. In: Parents and children, man and women in Family and Society, edited by Tatiana Maleva and Olga Sinyavskaya , pp. 421- 76. Moscow: Nezavisimyy Institut Sotsial'noi Politiki.

Snarskaya, Olga. 2009. Sexual'noe obrazovanie kak sfera proizvodstva gendernyh razlichii i konstruirovania predstavlenii o „natsii“ [Sexual education as the field of production of gender differences and construction of 'nation']'. In: Zdorov'e $i$ doverie: cendernyi podhod $k$ reproduktivnoi meditsine [Health and trust: a gender approach to reproductive medicine],edited by Elena Zdravomyslova and Anna Temkina, pp. 51-90. St. Petersburg: EUSPb

Temkina, Anna. 2008. Zhenskaia seksual'nost': mezhdu podchineniem i svobodoi [/Women's sexuality: between freedom and subordination]. St. Petersburg: European University of St Petersburg Press.

Temkina Anna and Elena Zdravomyslova. 2005. Gendered citizenship in Soviet and post-Soviet societies. In: Gender and nation in contemporary Europe, edited by Vera Tolz and Stephanie Booth, pp. 96-115. Manchester: Manchester. University Press.

Vishnevskii, Anatolii (ed.). 2006. Demograficheskaia modernizatsiia Rossii 19002000. [Demographical modernization of Russia 1900-2000]. Moscow: Novoe izdatel'stvo.

Vovk E. 2006 Gendernaya asimmetryia i zhenskie roli v sovremennoi Rossii [Gender asymmetry and women's roles in contemporary Russia]. Demoscope weekly [online] № 249-250, 5-18 June 2006. [cited 10 October 2010]. Available from <http://www. demoscope.ru/weekly/2006/0249/analit03.php $>$

Westoff, Charles and Jenny Higgins. 2009. Relationships between men's gender atitudes and fertility: Response to Puur et al.'s "Men's childbearing desires and views of the male role in Europe at the dawn of the 21st century". Demographic Research [online] 10 July 2009, vol. 21, article 3 [cited 10 October 2010]. Available from $\leq$ www.demographic-research.org $>$

Zakharov, Sergei/ 2008 Russian Federation: from the first to second demographical transition. Demographic Research [online] 1 July 2006, vol. 19, article 24 [cited 10 October 2010]. Available from $\leq$ www.demographic-research.org $>$

Zakharov, Sergei and Viktoriya Sakevich. 2008. Osobennostu planirovanita sem'i I rozdaemost'v Rossii: kontratseptivnaya revolutsiya - svershivshiisya fakt? [Family planning and fertility in Russia: contraceptive revolution as a matter of fact]. In: Parents and children, man and women in Family and Society, edited by Tatiana Maleva and Olga Sinyavskaya, pp. 127-70. Is 1 Moscow: Nezavisimyy Institut Sotsial'noi Politiki,

Zdravomyslova, Elena. 2009. Nyani: kommerstializatsiya zaboty [Nanny; commercialization of care]. In: Novyi byt $v$ sovremennoi Rossii: gendernye issledovaniya povsednevnost [New byt in contemporary Russia: Gender studies of everyday life], edited by Elena Zdravomyslova, Anna Rotkirch and Anna Temkina, pp. 94-136. St. Petersburg: EUSPb

Zdravomyslova, Elena, Anna Rotkirch, and Anna A. Temkina. (eds.). 2009. Novyi 
byt $v$ sovremennoi Rossii: gendernye issledovaniya povsednevnosti [New Byt in contemporary Russia: Gender studies of everyday life]. St. Petersburg: EUSPb

\section{Appendix: List of informants}

Alena, 24 years, post-graduate student, married, daughter 1,5 year, Samara, 2009

Alisa, 22 years, sociologist, in stable partnership, Kazan' 2009

Alla, 23 years, economist, manager of personal, divorced, child, in stable partnership, Samara 2009

Anna, 28 years, architect, divorced, child, lives in cohabitation, Kazan' 2009

Anton (male), 30 years, an engineer, manager in private company, lives in cohabitation for 9 month, He is going to marry soon and to give birth to a child, St. Petersburg, 2009 Ekaterina, 27 years, cohabitation, is going to marry, pregnant Arkhangelsk 2009

Kira, 36 years, divorced, an engineer in pharmacological company, St. Petersburg 2004 Mila, 23 years, stable partnership, is going to marry, not working, BA in economics, wants to have a child, Kazan 2009

Nina, 22 years, single, interpreter in international company, St.Petersburg, 2005

Nadya, 22 years, stable partnership, want to have a child, Arkhangelsk 2009

Nataliya, 26 years, second time married, lawyer, Samara 2009

Nona, 22 years, student, married, one child, Arkhangelsk 2009

Yulia, 27 years, lives in cohabitation with a child's father for 3 years, a 3 years old child, school teacher, St. Petersburg, 2009

Vera, 21 years, student, stable partnership, Kazan' 2009

Veronika, 22 years, manager of personal in large corporation, lives in cohabitation, Samara 2009

\section{Cited couples:}

(1) Katiya, 29 years, lives in cohabitation with Yuri for 8 years, the director of a large department firm. They are going to marry soon and to give birth to a child, St.

Petersburg, 2009

Yuri (male), 32 years, lives in cohabitation with Katiya for 8 years, an engineer in high-technology. They are going to marry soon and to give birth to a child, St. Petersburg, 2009

(2) Natasha, 27 years, psychologist, lives in cohabitation with Dmitry for three years, works in private corporation. They are going to marry soon and to give birth to a child, St. Petersburg, 2009

Dmitry (male), 30 years, sociologist, lives in cohabitation with Natasha for three years, works in the same private corporation. They are going to marry soon and to give birth to a child, St. Petersburg, 2009 